\title{
The Relationship between Social Support and The Psychological Well-being of Students Who Work Part-time
}

\author{
Tubagus M Nashich ${ }^{1,2}$, Listyati S Palupi ${ }^{1,2,3 *}$ \\ ${ }^{1}$ Personality and Social Psychology Department, Faculty of Psychology, Airlangga University, \\ Surabaya, Indonesia \\ ${ }^{2}$ Health and Environmental Sustainability Research Group, Faculty of Psychology, Airlangga \\ University, Surabaya, Indonesia \\ ${ }^{3}$ Adiction Study Centre, Airlangga University, Surabaya, Indonesia
}

\begin{abstract}
Higher education student often experienced financial problem during their study. This condition encourages them to seek financial support by working part-time. The challenge of being a part-time employee as well as being a student has influenced their psychological well-being condition. The problem will become more complicated when they received less than needed social support. Therefore, it is important to identify the relationship between social support and psychological wellbeing of part-time students. This study aimed to determine the relationship between social support and psychological well-being of students who work part-time. This research is a quantitative survey research. The scale used was social support and psychological well-being scale. The study shows that social support has a significant relationship with psychological well-being. Hypothesis test result show positive value that means if social support increase, psychological well-being will also increase. The correlation coefficient of 0.433 shows the relationship between variable classified as moderate.
\end{abstract}

\section{Introduction}

Humans have various types of needs that are increasing and complex. One of the important needs is the need for education. However, to pursue higher education is not easy, a student must meet various kinds of obligations, such as paying for university, buying stationery, buying textbooks, photocopying fees, training costs, and other expenses related to the university. Not to mention added to the cost of daily necessities such as meals, boarding fees, gasoline, and others [1].

Given the very diverse and increasing needs of students, parents no longer able to bear the overall costs of higher education [2]. This makes students have to find ways to meet all their needs, both the needs for education and daily needs. There are students who decide to go to university while working to meet those needs. However, so that they are still able to carry out lecture activities, the work taken by students in general is a type of work such as

\footnotetext{
*Corresponding author: listyati.palupi@psikologi.unair.ac.id
} 
part-time work [3]. The phenomenon of working students is called the dual role phenomenon [4].

Besides the desire to live independently so as not to depend on parents, there are many other things that made students choose to do a part-time job which are filling their free time on the sidelines of lecture schedules, looking for non-academic experiences, or just doing a hobby [5].

However, carrying out the obligation to study and also have to work certainly will not be easy for a student. CNN Indonesia said on its website that students who work tend to experience mental problems. Dadgar (2014) also found another fact that students who were unable to balance work and college activities were one of the reasons that influenced the dropout rate [6]. This shows that work activities affect the activity of college students themselves.

This is because there are two demands in two different places. A student who works will experience a dual role conflict in meeting the demands of his role as a student and also as an employee. This circumstances could have negative impacts such as decreased mood, decreased level of physical health, decreased productivity and substance abuse [7]. Even worse if the stress due to role conflict is not immediately resolved and continues for a long time will result in burnout. This causes a student who also works will experience stress which will affect his well-being [8].

There are several factors that affect psychological well-being, so that not everyone has the same level of psychological well-being. Existing studies show that there is no single determinant and welfare. Some conditions seem necessary for achieving high psychological well-being such as mental health and positive social relationships [9]. Based on the opinion of Yasin \& Dzulkifli (2010) that there is a relationship between social support and psychological well-being of students [10].

Social support itself is a variety of resources provided by others to individuals that can affect the welfare of the individual concerned [11]. Sarafino (2002) says social support can take the form of several forms such as emotional support, appreciation support, instrumental support, information support, and social network support [12]. The benefits and social support is to reduce anxiety, depression, and symptoms of bodily disorders for people who experience stress [13]. Individuals who have high social support will have positive experiences in their lives, such as high self-esteem, and lower anxiety levels so as to increase the level of psychological well-being.

Measurement of social support itself is not easy because social support is considered as something useful when the individual needs and perceives the availability and social support [14]. The same opinion was expressed by Barrea (1981) that well-being correlates with subjective aspects and social support. This means that the individual's perception of social support is a more important factor than the form or amount of social support received by the individual [15].

The importance of social support in increasing psychological well-being need especially for students that have a part-time job while studying need to be explore. Therefore, researchers conducted further research on the relationship between social support and psychological well-being of students working part-time.

\section{Method}

This research using quantitative method with associated descriptive approaches. The subjects of this research are students in Airlangga University Surabaya who work part-time. The instrument used by researchers consisted of questionnaires. The data collection technique in this study is a survey technique, while the subject taking technique uses Snowball Sampling. Social support is measured using Multidimensional Scale Perceived Social Support (MSPP) 
developed by Zimet [16] and Psychological Well Being is measured by Javanese Psychological Well-being Scale developed by Palupi [17].

\section{Data and Results}

Table 1. Demography

\begin{tabular}{ll|ll}
\hline \multicolumn{2}{l|}{ Characteristics } & \multicolumn{2}{c}{ Frequency } \\
\hline $\mathrm{N}$ & & 65 & $100 \%$ \\
\hline Gender & & & \\
& Male & 23 & $35.39 \%$ \\
& Female & 42 & $64.61 \%$ \\
\hline Age & & & \\
& 18 & 1 & $1.54 \%$ \\
& 19 & 5 & $7.69 \%$ \\
& 20 & 9 & $13.85 \%$ \\
& 21 & 16 & $24.62 \%$ \\
& 22 & 23 & $35.39 \%$ \\
& 23 & 9 & $13.85 \%$ \\
24 & 1 & $1.54 \%$ \\
25 & 1 & $1.54 \%$ \\
\hline
\end{tabular}

It can be seen that the number of subjects contained in this study were 65 subjects. There were $23(35.39 \%)$ male subjects, and 42 (64.61\%) female subjects. Based on the age, there is $1(1.54 \%)$ subject who is 18 years old, there are $5(7.69 \%)$ subjects who are 19 years old, there are $9(13.85 \%)$ subjects who are 20 years old, there are $16(24.62 \%)$ subjects who are 21 years old, there are $23(35.39 \%)$ subjects who are 22 years old, there are $9(13.85 \%)$ subjects who are 23 years old, there is $1(1.54 \%)$ subject who is 24 years old, and there is 1 $(1.54 \%)$ subject who is 25 years old.

Table 2. Descriptive Analysis Statistic

\begin{tabular}{l|l|l}
\hline & Psychological Well-being & Social Support \\
\hline $\mathrm{N}$ & 65 & 65 \\
\hline Mean & & \\
$\quad$ Statistic & 29.68 & 65.37 \\
$\quad$ Std. Error & 0.503 & 1.620 \\
\hline Std. Deviation & 4.055 & 13.062 \\
\hline Skewness & & \\
$\quad$ Statistic & -0.907 & -1.283 \\
$\quad$ Std. Error & 0.297 & 0.297 \\
\hline Kurtosis & & \\
$\quad$ Statistic & -0.116 & 1.498 \\
$\quad$ Std. Error & 0.586 & 0.586 \\
\hline Minimum & 18 & 22 \\
\hline Maximum & 35 & 84 \\
\hline Range & 17 & 62 \\
\hline
\end{tabular}

It can be seen that the psychological well-being variable has the highest value of 35 , the lowest value of 18 , and the range of 17 . While the social support variable has the highest value of 84 , the lowest value of 22 , and the reach of 62 . The psychological well-being variable 
has an average value of 29.68 with standard deviation of 4,055 . While the social support variable has an average value of 65.37 with a standard deviation of 13.062 .

It can be seen that the variables of psychological well-being and social support show skewness values of -0.907 and -1.283 . A negative value on skewness indicates that the variable data distribution curve has a tendency towards the left. The value of kurtosis on the variables of psychological well-being and social support is -0.116 and 1,498 . The value of kurtosis represents the sharpness of the data distribution curve.

Table 3. Correlation Test Result

\begin{tabular}{l|l|l}
\hline & & Social Support \\
\hline Psychological Well-being & Correlation Coefficient & 0.433 \\
& Sig. (2-tailed) & 0.000 \\
& N & 65 \\
\hline
\end{tabular}

In the table above shows the complete amount of data that is 65 data and no missing data. It can be seen that the significance value of two variable is 0.000 , where the significant value is less than 0.05 which can be interpreted that there is significant relationship between two variables. In other words, there is a significant relationship between social support and psychological well-being. The result of the correlation coefficient shows 0.433 , so it can be concluded that there is a moderate relationship.

\section{Discussion}

This study proves that there is a significant relationship between social support and psychological well-being. The result is in line with the previous study conducted by Yasin \& Dzulkifli (2010) that there is a relationship between social support and psychological wellbeing of students [10]. Cohen and Syme (2005) has come to the same conclusion that social support is closely related to psychological well-being [11].

Research shown that students that received a high social support will have high level of psychological wellbeing. Apollo \& Cahyadi (2012) found that the benefits of social support are to reduce anxiety, depression, and symptoms of bodily disorders for people who experience stress [13]. Therefore, individuals who get high social support will have positive experiences in their lives, such as high self-esteem, and lower levels of anxiety, so as to increase psychological well-being.

Given that students who work part-time are individuals who are vulnerable to mental disorders because they have to work on two roles simultaneously. In this context, social support is an important external factor that could help them in improving their psychological well-being.

\section{References}

[1] E. Mardelina and A. Muhson, "MAHASISWA BEKERJA DAN DAMPAKNYA PADA AKTIVITAS BELAJAR DAN PRESTASI," Jurnal Economia, (2017).

[2] J. A. Lenaghan and K. Sengupta, "Role Conflict, Role Balance and Affect: A Model of Well-being of the Working Student," Hofstra University, (2007).

[3] M. H. J. Wolbers, "Learning and working: double statuses in youth transitions within the European Union," Maastricht, (2001). 
[4] P. Robert and E. Saar, "Learning and Working: The Impact of the "Double Status Position' on the Labour Market Entry Process of Graduates in CEE Countries," European Sociological Review, p. 742-754, (2012).

[5] S. F. Daulay and F. Rola, "Perbedaan Self Regulated Learning antara Mahasiswa yang Bekerja dan yang Tidak Bekerja," Universitas Sumatera Utara, (2009).

[6] M. Metriana and E. Lataruva, "Studi Komparatif Pengaruh Motivasi, Perilaku Belajar, Self-Efficacy Dan Status Kerja Terhadap Prestasi Akademik Antara Mahasiswa Bekerja Dan mahasiswa Tidak Bekerja (Studi Pada Mahasiswa S1 Fakultas Ekonomika Dan Bisnis Universitas Diponegoro)," Semarang, (2014).

[7] C. Finney, E. Stergiopoulos, J. Hensel, S. Bonato and C. S. Dewa, "Organizational stressors associated with job stress and burnout in correctional officers: a systematic review," BMC public health, (2013).

[8] R. Buda and J. A. Lenaghan, "Engagement in Multiple Roles: An Investigation of the Student-Work Relationship," Journal of Behavioral \& Applied Management, (2005).

[9] C. D. Ryff, "Psychological well-being in adult life," Current directions in psychological science, (1995).

[10] A. S. \&. D. M. A. Yasin, "The relationship between social support and psychological problems among students," International Journal of Business and Social Science, p. 1, (2010).

[11] S. E. Cohen and S. L. Syme, Social support and health, London: Academic Press, (2005).

[12] E. P. Sarafino, Health Psychology Biopsychosoctal Interactions Fourth Ethtion, United States: John Wiley \& Sons, Inc, (2002).

[13] Apollo and A. Cahyadi, Konflik peran ganda perernpuan menikah yang bekerja ditinjau dari dukungan sosial keluarga dan penyesuaian diri, Widya Warta, (2012).

[14] J. Bruhn and B. Philips, "Measuring social support: A synthesis of current approaches," Journal of Behavioral Medicine, (1984).

[15] E. P. Sarafino and T. W. Smith, Health psychology: Biopsychosocial interactions, USA: John Wiley \& Sons, Inc, (2011).

[16] G. D. Zimet, N. W. Dahlem, S. G. Zimet and G. K. Farley, "The Multidimensional Scale of Perceived Social Support.," Journal of Personality Assessment, pp. 30-41, (1988).

[17] L. S. Palupi, "Psychological Wellbeing of Elderly People in Indonesia: Javanese Psychological Wellbeing Perspective," Studia Universitatis Moldaviae, pp. 177-180, (2018). 